
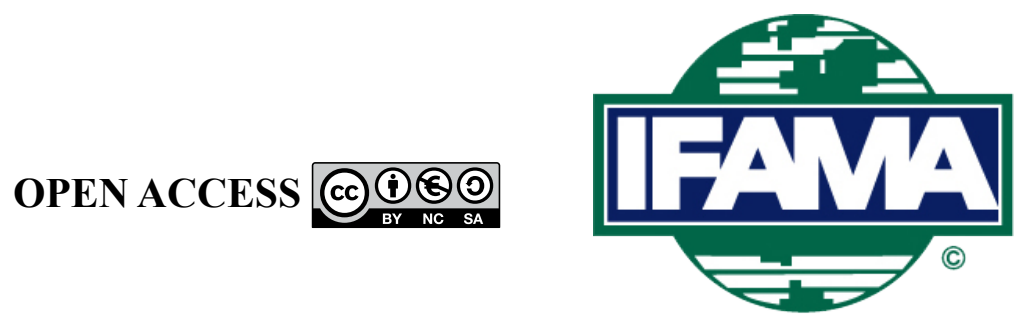

International Food and Agribusiness Management Review

Volume 22 Issue 5, 2019; DOI: 10.22434/IFAMR2018.0091

Received: 10 September 2018 / Accepted: 3 July 2019

\title{
Dairy supply chain in Southern Brazil: barriers to competitiveness \\ RESEARCH ARTICLE
}

\author{
Caetano Luiz Beber ${ }^{\oplus a}$, Andres Fabricio Ruales Carpio ${ }^{\mathrm{b}}$, Mohamad Isam Almadani ${ }^{\mathrm{c}}$ \\ and Ludwig Theuvsen ${ }^{\mathrm{d}}$
}

${ }^{a}$ Research associate, ${ }^{b}$ Student and ${ }^{d}$ Professor, Department of Agricultural Economics and Rural Development, Chair Economics of Agribusiness, Georg-August-University of Goettingen Platz der Göttinger Sieben 5, 37073 Göttingen, Germany

${ }^{c}$ Research associate, Institute of Farm Economics, Johann Heinrich von Thünen Institute, Bundesallee 63, 38116 Braunschweig

\begin{abstract}
The Brazilian dairy industry is still in its infancy, especially in regards to competitiveness on foreign markets. Therefore, it is facing difficult challenges to upgrade in terms of professionalisation, productivity and technological improvements, but also to avoid exclusion of small-scale farms. This study identifies the main factors affecting the competitiveness and slowing the modernisation of the supply chain in one of the most promising and dynamic dairy production areas in the world - the mesoregion 'Grande Fronteira do Mercosul' in Southern Brazil. The analysis is based on the perceptions of supply chain leaders about the challenges to improving the industry's competitiveness. The paper also presents various strategies already implemented by some actors to overcome such barriers to competitiveness. The empirical results have manifold implications. One of which is that the problems and strategies must be the target of managers and authorities in a sustainable common project of development to the benefit of the whole dairy supply chain.
\end{abstract}

Keywords: dairies' competitiveness, dairy supply chain, Brazilian dairy sector JEL code: Q13, Q16

\footnotetext{
${ }^{\oplus}$ Corresponding author: cbeber@uni-goettingen.de
} 


\section{Introduction}

The Brazilian dairy industry has experienced a rapid and significant growth since the 1990s, mainly driven by the production in the mesoregion 'Grande Fronteira do Mercosul (GFM)', located in Southern Brazil ${ }^{1}$. Its production is mostly based on family farms and cooperatives and, as the dairy sector becomes increasingly competitive, is growing faster than in all the other regions in the country (Anschau, 2011). For instance, in 1992 the Brazilian milk production accounted for only 15.8 billion liters. In 2006, production quantities had increased to 25.4 billion liters of which $13.3 \%$ was produced in the GFM. By 2015 it was already the largest dairy production area in the country, accounting for roughly $18.5 \%$ (6.46 billion liters) of the national production of 35 billion liters. 420 companies were responsible for the collection and processing the raw milk of 288 thousand farms in the Southern region (IBGE, 2017). The dairy production has a high socioeconomic importance ${ }^{2}$ in this region, generating incomes and jobs.

However the dairy sector in the whole country, including the GFM, does not show the high competitiveness traditionally present in many Brazilian agricultural sectors such as soybean, maize, pork, poultry, sugarcane and beef (Helfand et al., 2015; Mueller and Mueller, 2014). The domestic dairy production has not been able to supply the internal market with products of higher quality and quantity, even less to the export market that is more stringent in terms of quality and regular demand. Given this context and the pressure of the economic environment, which is increasingly competitive, cooperatives and some national private companies have been facing hard challenges to compete and persist in the market, especially in GFM. Their collapse would see the exclusion of small producers from the market, and the reduction of a source of income and employment for those families. Therefore improving the competitiveness of producers and processing companies in this supply chain may generate important socioeconomic gains in this area.

Competitiveness has different origins depending on the sector assessed (Kennedy et al., 1997). What is known is that those factors are framed by the external conditions: the politico-economic situation, technological conditions, and market characteristics (Porter, 1980), among others. But given that external conditions are the same or similar across a country, in our case Brazil, why does the dairy sector present such a competitiveness gap when compared to other agricultural sectors? It is a controversial issue that must be addressed by this emerging economy from a rural development and economic growth perspective.

It is important to note that as an emerging economy, some sectors will be more developed than others indeed, in some cases serving as an economical subterfuge to encompass the less favored population still existing in those countries. Therefore, the next step in the national development plan must be to prioritise the inclusion of the work force in those areas in a more professional, competitive and global modern supply chain. To this end, we conducted this study to investigate what were the main problems faced in the dairy sector, what the possible drivers of competitiveness and why it is less developed compared to other agricultural sectors in Brazil.

The analysis of competitiveness requires the examination of the underlying factors that influences the individual firms and industries (Batalha and Souza Filho, 2009; Kennedy et al., 1998; Martin et al., 1991; Neves et al., 2013), but there is little consensus in the literature on how to measure it. In our analysis, we adopted the framework proposed by Harrison and Kennedy (1997). They suggest five primary sources of competitiveness that might affect the firms' profits and market shares (Porter, 1985). These sources are: technology, attributes of purchased inputs, product differentiation, production economies and external factors, which can provide superior levels of competition to firms, when improved.

\footnotetext{
${ }^{1}$ The South of Brazil comprises three states: Paraná, Santa Catarina and Rio Grande do Sul.

2 In GFM $60 \%$ of the farms produced milk as their main or secondary product in 2006 . That makes a total of 182 thousand farms producing milk. According to the Brazilian Institute of Geography and Statistics (IBGE (2006)), this milk generated US \$396 million in total in the same year, representing $9.2 \%$ of agricultural GDP and $2.7 \%$ of the total GDP in the GFM - which, in turn, corresponds to an average of US\$2,000 per farm/year.
} 
Different factors have been identified in the literature that might influence those sources, serving as possible drivers of companies' competitiveness (or its lack). Technology diffusion and adoption is considered to be one of the most important (Solow, 2001). It would drive competition by originating structural changes, contributing to efficiency and productivity gains, improvements of working conditions, and cost reduction and provides high responsiveness in a constantly changing environment (Schwab et al., 2015). This feature becomes especially evident in emerging economies where increases to the middle-class population are shifting consumer preferences from the massive consumption of bulk products to quality consumption of more differentiated food products. Other factors identified in the literature include professionalisation of human resources; availability of technical assistance; well-planned investments; adequate infrastructure and policies; productivity; access to external markets and the quality of management, among others (Carraresi and Banterle, 2015; Chaddad, 2007; Ndiaye et al., 2015; Nivievskyi, 2012). Market actors and their linkages (vertical and horizontal coordination), collective actions and supporting industries, for instance service providers, also have a particular importance in the dairy supply chains and might affect the competitiveness (Albu and Griffith, 2006; de Brito et al., 2015; Farina, 2003; Hudson, 1990).

However there are only few studies which attempt to provide an analysis of competitiveness through looking at the processing stage of a supply chain in an emerging economy context, where some areas and sectors show indices of developed countries, alongside to others with indices of developing countries. That is one of the interests in GFM, in Southern Brazil, which has a large amount of family farms present in the zone, and the dairy sector has a high potential in contributing towards the livelihoods of these families. In this light, the GFM case might be seen as a blueprint for similar sector conditions in many emerging and developing economies. This study gives a global perspective on the supply chain, drawing management and policy recommendations derived from information provided by industry leaders. To our knowledge this is the first study using this approach for the GFM dairy supply chain.

The article is organised as follows: in the opening section, we present a background on competitiveness for the GFM. In sequence we describe the methods employed followed by a description of the data. Next, the major results are presented and discussed. Lastly, the article ends with the conclusions and policy implications.

\section{Competitiveness of GFM dairy supply chain}

Several definitions of competitiveness are found in the literature, which might focus on the different sources and indicators of competitiveness depending on the research objectives of each study (e.g. Cook and Bredahl, 1991; Feurer and Chaharbaghi, 1994; Kennedy et al., 1997); but little consensus exists. Porter (1980) provides a well-accepted and largely adopted definition of competitiveness: 'the ability to profitably create and deliver value through cost leadership or product differentiation (customer value)'. It was further extended to include indicators of competitiveness: 'the sustained ability to profitably gain and maintain market share' (Porter, 1985).

In a dairy supply chain perspective, both cost leadership and the customer benefit approach are applicable. Downstream, product differentiation is essential for companies to achieve a competitive advantage, but since a large number of close substitutes exist in the markets where they operate, prices and costs must not be neglected. Companies' costs might also highly vary because of management shortcomings and inefficiencies on the processing plants. In GFM dairy supply chain, companies face a high competition for both resources (milk purchase) and for sales of dairy products. Therefore, the definition of competitiveness provided by Cook and Bredahl, (1991) seems more appropriate and it is adopted in this paper. It is itself a further extension of Porter's (1985) and (Sharples and Milham's (1990) definitions. Cook and Bredahl, (1991) define competition as the 'ability to deliver goods and services at the time, place, and form sought by buyers at prices as good or better than other suppliers while earning at least the opportunity costs on resources employed' in a specific market. Therefore, according to this definition, in order to understand more specifically the mechanisms refraining or boosting the competitiveness capacity of dairy supply chain in GFM, in the next paragraphs we will situate it in an agribusiness context. 
Despite the large potential, significant investments and the fast development of the agricultural sector in Brazil, the dairy supply chain is suffering a much slower process of improvements with regard to productivity and modernisation. Today the dairy sector runs far behind, in terms of competitiveness, compared to other sectors in the country's agriculture such as soybean, maize, pork, poultry, sugarcane and beef where the modernisation started earlier and received many incentives (Helfand et al., 2015; Mueller and Mueller, 2014). This also holds true in comparison to the dairy sector of neighboring countries, such as Argentina and Uruguay, and other countries with similar production systems and environmental conditions. The Brazilian dairy sector has not exploited its full potential. To illustrate, we take a closer look at a few indicators and characteristics of this supply chain.

Although ranking fourth in the world production of milk and showing a constant growth, Brazil presents an extremely low productivity in dairy farming, with less than $1,600 \mathrm{~kg} / \mathrm{cow} /$ year $\left(97^{\text {th }}\right.$ position in productivity ranking of FAO), while New Zealand for example, with a similar pasture-based system and pedo-climatic conditions like Brazil, produces approximately $4,500 \mathrm{~kg} / \mathrm{cow} / \mathrm{year}$. The neighboring countries Argentina and Uruguay also show higher productivities, 5,646 and 2,890 kg/cow/year respectively in 2014 (FAO, 2014). This is also indicated by sector statistics of the three states in the Southern region (Rio Grande do Sul, Santa Catarina and Paraná) (Figure 1). Thereby, the productivity average of states regions together in 2014 was 2,790 liters $^{3} /$ cow/year (IBGE, 2016).

Only the state of Rio Grande do Sul reached the level of 3,000 liters/cow/year in 2014 (IBGE, 2014), which was still very low in the international context. Since data is collected in GFM, from 1990, it shows higher productivities compared to the national levels. In 2014 even though low, this number was already superior to 3,200 liters/cow/year.

The country's herd decreased to 17.1 million milk cows in 2017, while the productivity per cow increased by $29 \%$ (IBGE, 2017) led by Mina Gerais (62\%) and Santa Catarina (33\%), the most productive state in the country with 3,580 liters/cow/year. In GFM such productivity enhancement is even more remarked, mostly led by the West of Santa Catarina zone (Figure 2), where in 2017 the productivity already surpassed the

\footnotetext{
${ }^{3}$ Data from IBGE is presented in liters instead of $\mathrm{kg}$, which is the international standard. However the conversion from liters to kg only slightly changes since the density of raw milk is close to the unity, been usually found in the range of $1.026 \mathrm{~g} / \mathrm{cm} 3-1.034 \mathrm{~g} / \mathrm{cm} 3$ at $20^{\circ} \mathrm{C}$.
}

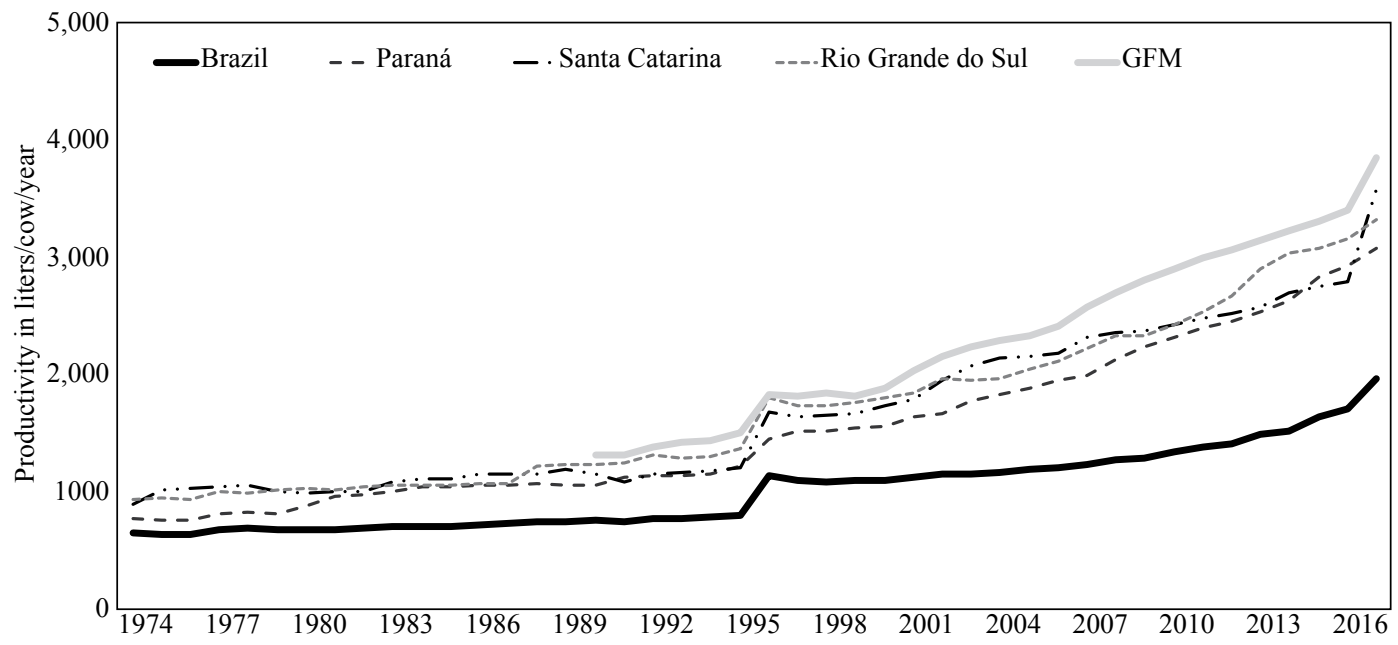

Figure 1. Productivity historic of Brazil, the three states of the Southern region and the Grande Fronteira do Mercosul (GFM). Source: IBGE, 2017.

In 1996 a new agricultural census was conducted in the country, updating the real number of producing cows in the country, much less than estimated, explaining the sharp increase in the productivities in this specific year. 


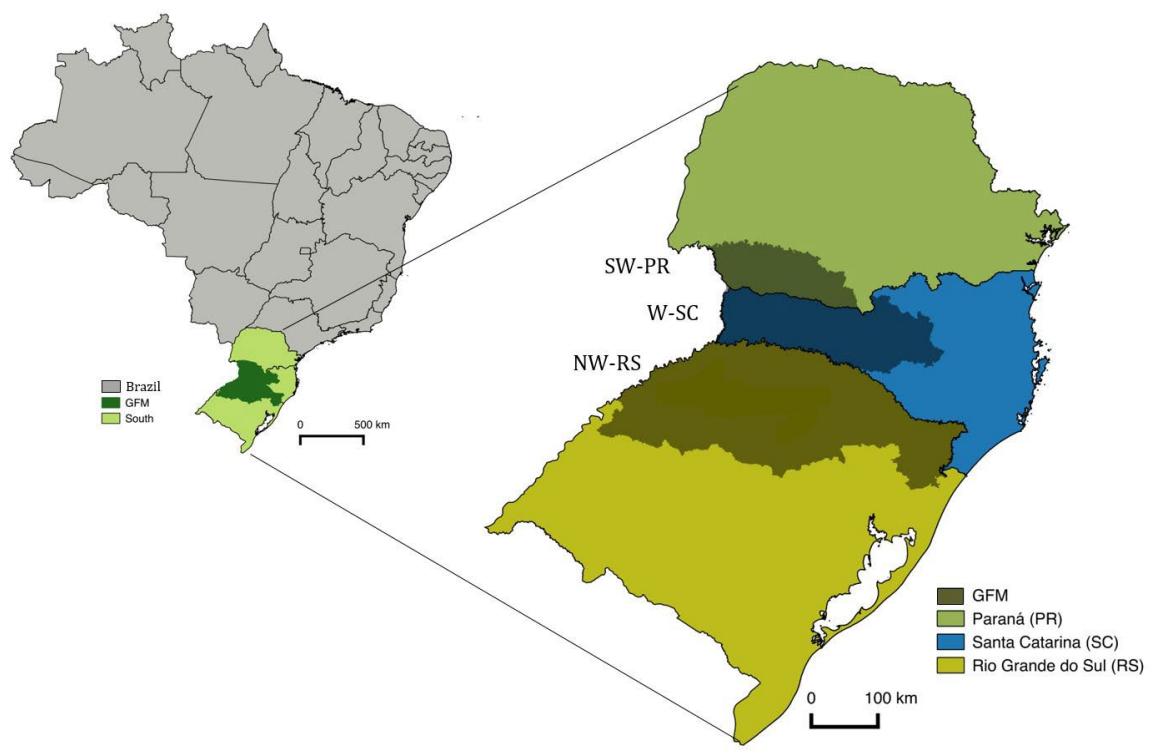

Figure 2. Map of Brazil with Southern Brazil and Grande Fronteira do Mercosul (GFM) highlighted (left). The three states of Southern Brazil and GFM shaded (right). Source: IBGE, 2014.

4,200 liters/cow/year. These recent developments highlight the structural changes taking place in Brazil and a higher technification of the production systems reflecting the efforts for efficiency and productivity gains.

Despite recent improvements, the last agricultural census of the IBGE (2006) presents parameters that show the reality of the low technology adoption in the dairy production at that time. For instance 'mechanical milking' was present in only $2.4 \%$ of farms representing $22 \%$ of the milk collected. Artificial insemination was present in $1.4 \%$ of farms representing $14 \%$ of the milk. Finally, only $11 \%$ of farms had cooling tanks.

This low technology adoption rates are also connected to low qualities of dairy outputs. A large part, $34 \%$ of the milk is still not complying with the quality and sanitary Federal Inspection System (SIF). In this regard, Brazil obtained the international sanitary certification to export to China only recently in the year 2015. In 2016 around $30 \%$ of the total milk production was self-consumed or traded in informal markets. About 1,969 companies processed the remaining $70 \%$. Small farms predominate; $84 \%$ own less than 50 ha corresponding to $60 \%$ of the total production quantity and $45 \%$ produced less than 10 liters/day (IBGE, 2017).

The country became self-sufficient in dairy production in 2003 . Thus, as the production increases, raising $315 \%$ from 1980 to 2014, reaching 35 bn liters, some of the sector's stress has been shifted to processors, who are now adjusting to a new reality by increasing their scale and professionalising in order to become more competitive. The national dairy processing companies have been struggling since the $1990 \mathrm{~s}$, when a late process of supply chain modernisation started, in which institutional changes were implemented such as trade liberalisation, deregulation of prices, imposition of public and private quality and safety standards and the creation of the sub-regional trade bloc 'Mercosur' (Chaddad and Jank, 2006). But even today, these processing companies are not able to supply the domestic demand with products of higher quality and quantity, even less to export. This is reflected in the trade balance, which is historically negative (Figure 3).

In 2016 the trade balance of dairy products with higher added value such as cheese, yogurt and derivates summed up to US\$ -141 million FOB, while the country's exports from the whole agriculture and agrofood industries totaled over US\$ 71 billion in 2016 (US\$ 60 billion positive balance), accounting for more than $40 \%$ of total national exports (FAO and OECD, 2015; IBGE, 2017). This represents the gap that exists between the dairy and the other agricultural sectors in the country. Another unfavorable indicator is the decreasing share of processed products in these exports, declining from 69\% in 2007 to $56 \%$ in 2016 (MDIC, 


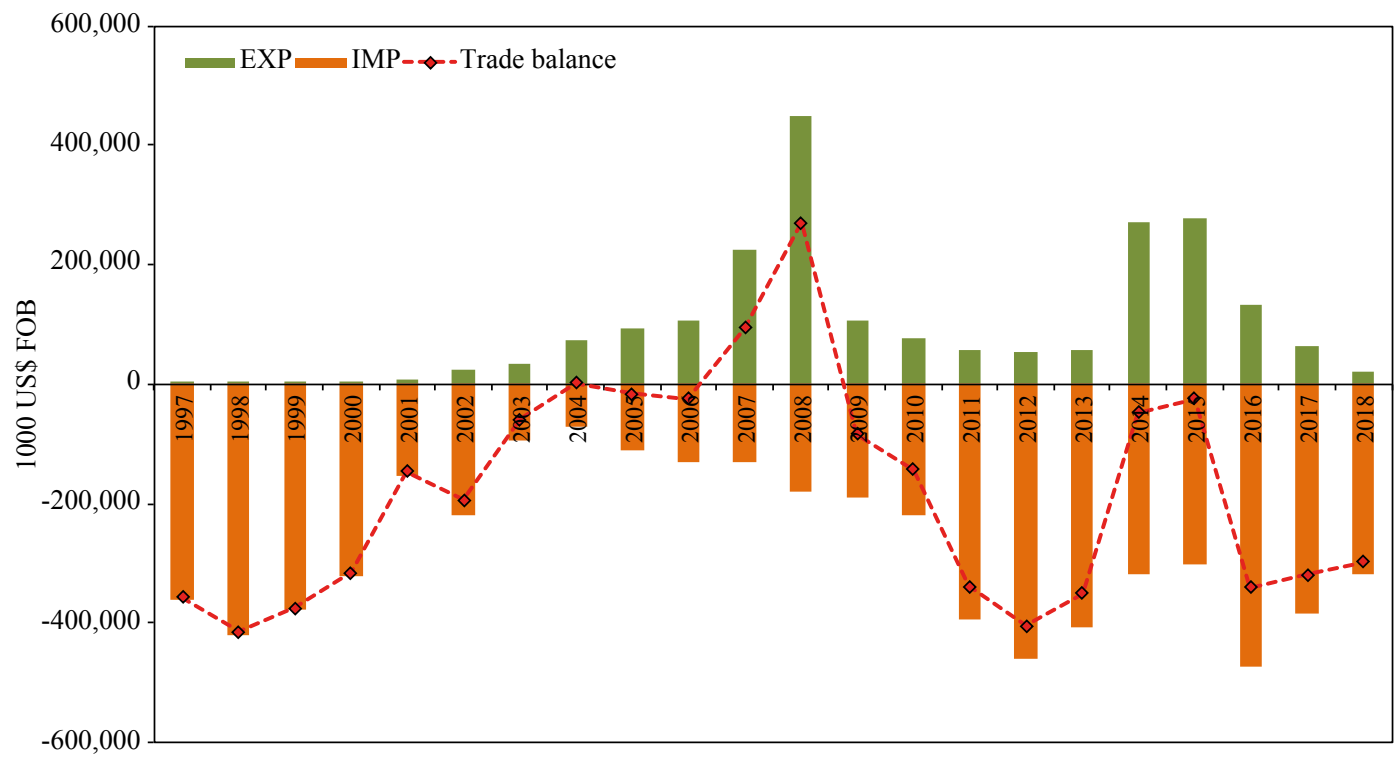

Figure 3. Trade balance historic (export and import) of Brazilian dairy production. Source: MDIC, 2019.

2016), representing a lower industrial intensification of added value products. In this regard low added value products such as basic cheese, powder milk, fluid milk and butter represented together $93.3 \%$ of the milk used in the industry in 2006 (Carvalho et al., 2007). Brazilian dairy exports account for less than $1 \%$ of the total world exports (FAOSTAT, 2019), being 2008 the best year, where it achieved 1.3\%, representing a low market share in the international market.

Previous experiences in the restructuring of modern globalised supply chains of other Brazilian agricultural sectors, such as pork and poultry in Southern Brazil for instance, revealed an intense exclusion of farmers initially and a subsequent inclusion of the remaining farmers on higher value markets (Escher, 2011; Ferrari et al., 2005). Most of those excluded farmers migrated to the dairy production and decided then to integrate and formed traditional cooperatives for milk collection and processing to overcome the power of buyers, controlling the processing chain link and the prices at this step (Chaddad, 2007). However the low productivity of small producers and the poor infrastructure of rural areas in Brazil increases a lot the costs per unit of output, especially for those cooperatives which collect the milk of smaller producers in remote areas (Carvalho, 2008) and thus, have an important social role. And today, after a late initiative started only in the 1990s, these companies are also facing a process of modernisation with the consequent restructuration of the supply chain.

For instance, there is a path of consolidation amongst dairy processors in Brazil, a trend that has been active in the country's dairy industry over the last few years, and continues to intensify, accelerated by various economic challenges. For example, in 2007 the fifteen largest dairies processed $30.7 \%$ of the national production, yet until 2016 this number raised to $41.7 \%$, with the two largest processing companies (foreign multinationals) processing together $14.3 \%$ of the total milk produced in the country (Milk Brazil, 2017). This means the exit of less efficient processors, not only cooperatives, but also private companies, and the exclusion of farmers.

For what concerns the government and professional institutions, in GFM they act by creating and proposing policies to promote the progress of the chain through studies and projects. But since this sector displays a huge competitive gap when compared to other agricultural sectors in Brazil, it leads us to believe that such actions are not sufficient or not efficient enough. Furthermore, the government is not looking at the dairy sector as it did decades ago with other sectors, on which Brazil is among the most competitive suppliers on the planet. Producers of soybeans, corn, poultry, pork, sugar cane and beef receive(d) high-level technology 
funded by the government via EMBRAPA ${ }^{4}$ and other institutes and credits with very low interest rates. They also had or still have access to the $\mathrm{CONAB}^{5}$ for production stocking among other support programs and good technical assistance. The dairy sector is still perceived as a 'social shelter sector' to protect small and less professional farmers, preventing rural exodus and ensuring employment. However, this perception is changing and processing companies thinking forward are pushing to enter the competitive market. So measures to enhance the competitiveness and support small producers and processors are fundamental, as they are in place in many countries. The executive-chief of EMBRAPA said that milk should be treated as a state matter: 'it's like this everywhere in the world. There is no country that works with free trade regarding milk'.

This scenario illustrates the competitive position of the dairy sector in GFM and Southern Brazil, and the difficulties it is facing in order to improve it. In the next section, we go deep into the sector by interviewing different actors and asking about the barriers the sector faces and the strategies in place to overcoming them. We situate each of these factors in the framework of competitiveness sources of Harrison and Kennedy (1997).

\section{Methods and data}

The research was conducted in the southern region of Brazil, in three states that form the mesoregion Grande Fronteira do Mercosul (GFM) according to the national standard coding system. The mesoregion comprises the Southwest zone of Parana, the West of Santa Catarina, and the Northwest of Rio Grande do Sul (Figure 2). Qualitative primary data was collected between November 2016 and January 2017.

For this study the sample size of twenty-six interviewees was set, across a spectrum of leadership roles in the dairy industry. We interviewed managers, directors and presidents of almost all the main dairy processing cooperatives and private companies (all large and medium enterprises) in the region, in addition to the leadership of organisations, associations and unions involved in the dairy sector in the zone, to collect opinions from different perspectives in this economic activity. Out of the twenty-six persons interviewed, eight represented central cooperatives, four private companies, four non-governmental bodies, five unions, four governmental bodies, and one an association. Throughout the text we refer to 'institutes' as all those stakeholders not directly involved in processing (cooperatives or private companies). We chose the main companies with operations in the region and the main institutes carrying out important actions to promote the supply chain. Some of the companies or cooperatives interviewed are the largest in the zone, representing in some cases more than 6,000 producers and covering areas in more than one state. When considering the subsidiaries, associations and alliances, they are on a larger scale and these organisations are usually dispersed all over the country. Together, the milk processed by the private companies and cooperatives of the whole sample represents $55 \%$ of the total milk production of the GFM, so more than half of the chain volume (3.55 billion liters/year) passes through these processing companies. For confidentiality purposes the interviewees are identified in the text with numbers, ranging from ID001 to ID026.

Data was collected using semi-structured interviews, which were individually prepared and guided to avoid missing important aspects of each respondent. Questions varied according to the target participants. They cover aspects of the background information of the interviewed and their relation/influence on the supply chain from an historical perspective; structural and organisational aspects; management aspects; governance environment; market dynamics and external factors; technology adoption and diffusion; attributes of purchased raw milk; product differentiation and commercialisation channels; future expectations and actions. They intended to capture the main problems and strategies factors that might have any effect on the five primary sources of competitiveness proposed in the framework developed by Harrison and Kennedy (1997) and the coordination between actors in the supply chain. Ten interviews were conducted in Rio Grande do Sul, eight in Santa Catarina and eight in the state of Paraná, showing a uniform spatial distribution in the zone. Each

\footnotetext{
${ }^{4}$ Brazilian Agricultural Research Corporation.

${ }^{5}$ Brazilian National Supply Company.
} 
interview lasted around one and a half hour on average. In few cases more than one person from the same institute or enterprise were interviewed.

After collection, the information was transcribed and a discourse/content analysis of the qualitative data was performed including codification, first round of analysis and recodification. We identified how the elements are related between each other and how they affect the five primary sources of competitiveness. From this process, and from the fundamental topics investigated in this study, the 'problems' and 'strategies' emerged (according to the interviewees' perceptions). As a result ten factors were identified as the main restrictions and levers to the competitiveness of firms in this supply chain that directly or indirectly affect one or more of the primary sources of competitiveness defined by Harrison and Kennedy (1997). The factors are: (1) human resources; (2) diffusion of technologies and techniques; (3) quality and sanitary aspects; (4) contracts; (5) communication and loyalty; (6) processing capacities; (7) investments; (8) transport costs; (9) entry of large companies; and (10) frauds.

\section{Results and discussion}

In general, all interviewees agreed that it is necessary to have some changes and investments in the corporations and at farm levels in order to increase the competitiveness and improve the efficiency in the chain.

- 'Efficiency arises from increases in technical assistance, reduction of idle capacities, industrial management, cost management in the industry and farms, better inspection services, and the loyalty of farmers' (ID005).

- 'Marketing, communication, management and invest more in RTDI (Research, Technology, Development and Innovation)' (ID023).

- Leaders are aware that 'the main problems of efficiency and productivity are the lack of professionalisation of the producers; immediacy of producers and industrials; lack of a deeper analysis and planning ...' (ID024).

Figure 4 summarises the main findings.

\section{O M P E T I T I V E N E S S}

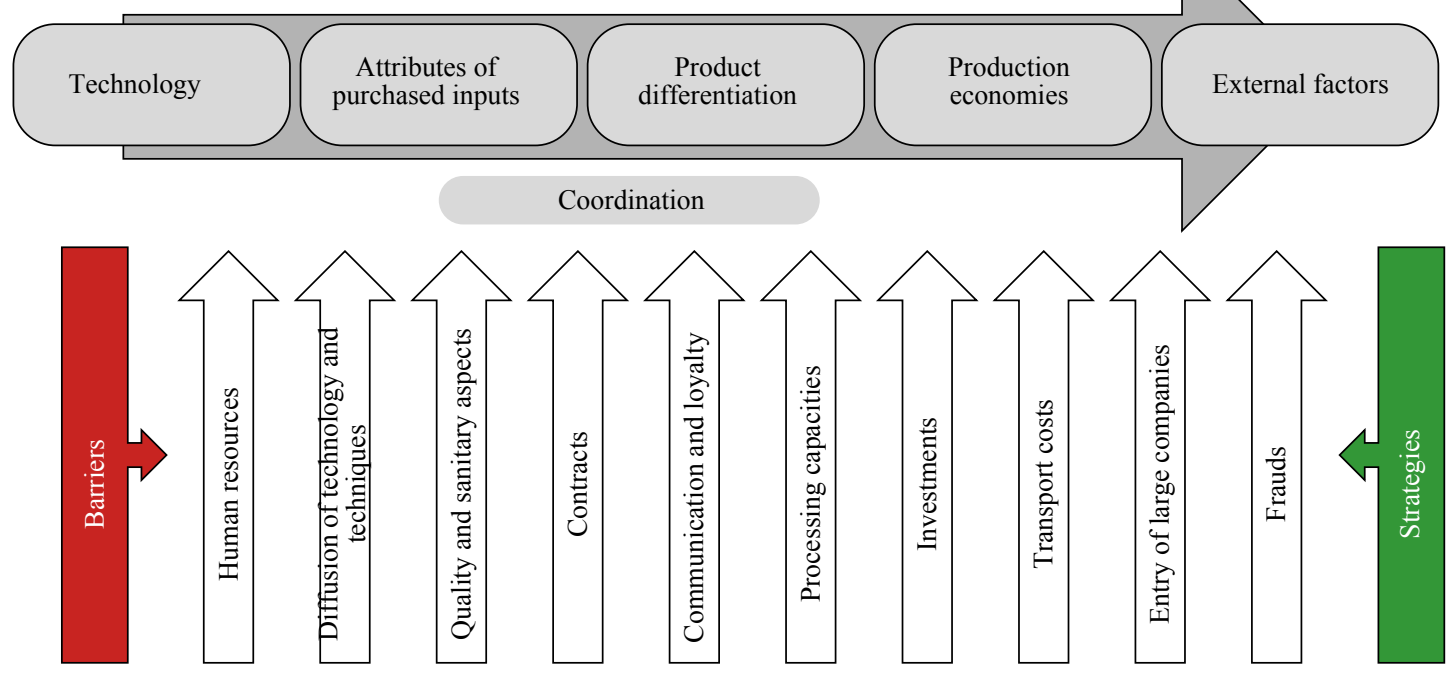

G F M D A I R Y S U P P L Y C C H A I N

Figure 4. Barriers and strategies influencing the competitiveness of Grande Fronteira do Mercosul (GFM) dairy supply chain. Adapted from de Brito et al. (2015). 
Next, we are going to analyze the main results of the interviews and discuss them. They are subdivided in ten factors mentioned in Section 3 (and Figure 4), according to their relevance as barriers affecting the level of competitiveness of the GFM dairy chain and the strategies implemented to deal with them.

\subsection{Human resources}

\section{- The barriers}

One of the main findings of our research is that the 'low professionalisation of the human resources' on the production and processing levels of the dairy chain may be the principal cause of several other problems. Lack of skilled labor at the processing plants and management teams are perceived as huge problems. At farm level, the problems are even more marked. Fifteen interviewees agreed that one of 'the weakest point in the chain is the professionalisation of the farmer management' (ID013) and that this significant problem needs to be fixed.

\section{- The strategies}

To mitigate such problems, several companies offer different forms of training for their employees in order to 'promote the internal growth, giving scholarships up to $40 \%$ to the employees, internal training in leadership, regulation, results, quality ...' (ID019). Furthermore, a '...central [cooperative] offers training in management to the singulars [cooperatives]' (ID015) as well as 'training to the technicians of the singular coops, and then those transfer the technologies to the farmers' (ID008). Not only companies, but also governmental and nongovernmental institutes offer different kinds of training, acting '... mostly in the articulation and enabling of events such as training and talks' (ID005). In total fifteen interviewees stated that they offer at least one or more types of training for the employees as well as to producers in many areas, including internal training, preparation for extension agents, field days, and others. The most frequently cited area of training was in management (mentioned eight times), followed by training in quality and hygiene (mentioned five times), and training for transporters (mentioned four times).

This problem is generally found in cooperatives where it is common that directors are in charge (elected) because of their political power inside the cooperative and not due to their technical or managerial specialisation - a situation which often results in inefficiencies and high costs (Benson, 2014). A study conducted by the 'Brazilian Micro and Small Business Support Service' SEBRAE found that leaders and directors of cooperatives are not well prepared to confront the changes and transitions in the sector, since investments are made without any market evaluation or viability study, milk collection is deficient, and there are many conflicts between singular and central cooperatives, and predatory behavior exists between cooperatives (Jank et al., 1999). On the other hand (Lopes et al., 2002) show that cooperatives which considered the professionalisation in their management important, and made adjustments accordingly, had higher performance in comparison with those that considered the professionalisation not so central. Theuvsen and Ebneth, (2005) also show that in order to adapt to new challenges in globalized agri-food markets, many cooperatives underwent a process of professionalising their management and the cooperative sector as a whole reveals a wide spectrum of professionalism and consequently very diverse financial performances. More educated managers may be able to use more diverse approaches for problem solving and decision making, which facilitates the adoption of innovations (Young et al., 2001).

It is not only the professionalisation of private companies and cooperatives which are important for the development of the sector, but also the support of institutes. They act mainly to propose policies, develop studies and projects to standardize and inspect the quality and sanitary aspects, or to promote the consumption of dairy products as well as training programs, among other initiatives.

The costs, quality and coordination of the human resources affect directly the competitiveness in the chain. Thus, in the framework of Harrison and Kennedy (1997), the human resources may be viewed as an input 
source of competitiveness. However the decision taken by people in all levels of the supply chain, including external factors may have an impact on other sources of competitiveness mentioned in the framework. Thus this factor must be foremost in all strategies aiming to improve the competitiveness of a supply chain.

\subsection{Diffusion of technology and techniques}

The transmission of technology and good practices for farmers is also affected by the low professionalisation at the processing level. Companies' managers must be highly qualified themselves in order to provide such assistance. At the production level, Lacki (1998) suggests that agricultural professionals should include in their objectives the transmission of knowledge to farmers in order to transform them into efficient and selfsufficient entrepreneurs. In this regard the World Bank is currently developing an exemplary project of how training and technical assistance can help to improve the competitiveness of farmers, private agro-firms, and development of rural communities in Uzbekistan. This results in the creation of new jobs along the entire value chain, increasing incomes, higher profits, and higher productivity (Khidirov, 2017).

\section{- The barriers}

The quality and productivity at farm level depends upon frequent and good technical assistance and the diffusion of technologies from processing companies. The current poor quality of assistance and its infrequent offering slows modernisation of the chain. Interviewees recognized that 'the only way to improve [competitiveness] is by increasing productivity and making farms viable to produce (ID019) through good farming techniques and animal genetics' (ID007). And this would only be possible through the diffusion of technology and techniques to producers. However only a small proportion of farmers are highly specialized in dairy production, in some cases making the necessary investments not affordable. This factor also seems to be hindering the competitiveness in GFM.

On the other hand, training organizers also complain about the negligence of some farmers saying that 'producers are not bad because of missing information, all have access if they want, ... but few producers participate' (ID017).

\section{- The strategies}

Some companies claim to offer a technical assistance, having ' ... a department for the promotion of quality, nutrition, silage, hygiene' (ID019) or even a 'a program of technical assistance to reduce the problem of seasonality. They work in the pasture, nutrition, pregnancy rate in the summer to search for stability in the production' (ID013). In total thirteen interviewees stated that the sector offers technical assistance - though it is precarious and lackadaisical - and the most frequently mentioned fields are quality and hygiene, and animal nutrition. In addition, most of the entities, which offer this service, are cooperatives, hence underlining the importance of these organisations in technology diffusion and farm management, which is also in line with the study conducted by de Brito et al. (2015) in the dairy chain of Paraná.

Although we found signs that there are programs for technical assistance and training in GFM, companies and institutes should offer more programs, with more frequency, and more excellence; covering themes of production, management, as well as sanitary practice and quality. This is in line with the thoughts of some interviewees from the institutes who said that producers needed to increase quality because it will be a cutoff requirement, and payments for quality are inevitable in the near future, especially with the entry of large companies. But first it is necessary to work with and offer more training to producers to increase their milk quality in order to avoid further exclusions.

The diffusion of technology and techniques affect directly the technology access as a source of competitiveness, by influencing the productivity enhancing and quality enhancing in the chain. 


\subsection{Quality and sanitary aspects}

Ten interviewees agree that an improvement of these parameters is essential, the implementation of inspection and quality control systems will be especially important if the industry aims to reach international markets. 'In order to export, the country has to develop a program of quality improvements to reach the international standards' (ID004).

\section{- The barriers}

'Quality and sanitary aspects are issues that must be improved in the supply chain' (ID012). The indices are too '...variable and difficult for industry standardisation' (ID015). Five interviewees said that is difficult to establish payments per quality or solids content because the market itself (consumers) does not pay differentiated prices, in some cases also because cooperatives have internal disputes. Producers' disloyalty is problematic because '...they migrate to other companies when they receive payments below the market value as a punishment for low quality. Some don't want to improve'(ID025).

\section{- The strategies}

It is possible that one of the first measures to enhance such quality, besides technical assistance, would be the payment for quality and solids. Indeed 'there is a tendency for payments per quality and solids because that's only what interests in milk production' (ID016). In this case payments are made by protein content and fat content because these two components are crucial to manufacture products with high added value; there are, therefore, bonuses or discounts over the base price because of these nutrients. In addition to the composition (solids), the quality is also determined by sanitary factors: the somatic cells count SCC and the total bacteria count TBC, for instance. These, in turn, influence the price to be paid. The requirements are based on regulatory standards to protect the human health. The Normative Instructions 51 and 62 of the Federal Government regulate such standards in Brazil.

Andri and Shiratake (2005) recommend that farms should work to increase quality and cooperatives should offer the proper price and strive for it. In large-producer countries, differentiated payments have been used for decades under the logic that paying for quality increases the benefits for producers and provides incentives to them to improve, consequently increasing benefits for the company (Madalena et al., 2001). Jank and Galan, (1998) consider that this problem is generalized in Brazil and the low quality of the milk that arrives at the processing stages discourages firms from differentiating prices.

Indeed, prices alone may not be efficient enough to transfer complex and rapidly changing information, especially regarding technological diffusion. Missing markets for information can slow adjustments on the part of producers and result in costly supply and quality shortfalls for firms that rely on spot markets for their product supply. Therefore, firms can solve the problem of missing markets for information by internalising the production process, or by employing production-management contracts (Key and Runsten, 1999). Production-management contracts are a good strategy to transfer specialized technology to producers. This is often the case in developing countries where firms want to locate a processing plant in a particular region but, at the same time, markets for inputs or services needed in the production are missing (Austin, 1981) - such as the case in GFM.

Quality and sanitary aspects affect directly the purchased Inputs from processing companies. They might be improved by the technology and information access, and specific external factors like governmental regulations to improve the inspection and extension services. 


\subsection{Contracts}

\section{- The barriers}

One of the most frequently mentioned problems in the sector is the establishment and enforcement of contracts between producers and processors. Most transactions are done on the spot. At the processing level, the disincentive to use contracts with small producers and the high transaction costs involved - associated with providing inputs, credit, extension services and product collection and grading (Key and Runsten, 1999), including the time and costs involved in the enforcement of such contracts - are, again, major discouragements. Almost all the interviewed processors stated that they currently work without contracts with producers; some of them used contracts in the past, but not anymore. At the production level, many farmers do not want or do not like to work under formal contracts, this is for a number of reasons: the lack of information and communication between buyers and producers; they do not take the dairy production seriously, seeing it as a second source of income and do not specialize and professionalize on its production; the judicial system is not effective enough or because it is a consequence of the poor management skills at farm level. In the analysis we found three main reasons why contracts do not work properly: judicial processes, seasonality of production, and disloyalty.

The general opinion is that '...contracts don't work because there is no judicial safety to enforce them' (ID018), '...the judicial costs are too high' (ID021) and they '... could be very slow' (ID010). Legal systems and crime prevention are poor in developing countries, especially in rural zones, and corruption represents a serious problem, so the protection of property rights and the contract enforcement can be problematic and costly (Brunetti et al., 1999; Tybout, 2000).

'There is also a problem with the seasonality of production, which makes it still harder to sign contracts' (ID012) where '...production and prices are instable along the year.' (ID004). In GFM the months with highest production are August and September, and the months with lowest are April and May, which represents a difference of about 46 million liters in 2016 (IBGE, 2017). Managers find it difficult to comply with contracts in terms of volume. Even though they are aware that "contracts would be interesting for warranties in volumes and prices, but seasonality is a huge problem to implement those.' (ID015).

Another major problem in implementing contracts is disloyalty and the free riders. 'Very infrequently contracts will be established for the sake of loyalty and selfish' reasons (ID005). Companies ' ... understand the importance of making contracts, but the producer does not' (ID014), in many cases they often seek the highest prices regardless of who pays due to the lack of future vision and communication.

\section{- The strategies}

No practical actions were identified among the interviewees for the establishment of contracts. To overcome missing contracts, other strategies to ensure the milk supply are used by the processing companies. The producers have created horizontal arrangements to reduce this problem. Cooperatives and associations were then formed, with higher volumes and lower frequency being transacted, thus, reducing its costs for the farmers. In this case the cooperatives incur these high costs, facing several difficulties as well, with the consequent abandon by its farmers.

Therefore a good contracting system should be enhanced and its benefits communicated to farmers ensuring their loyalty. It gives farmers the opportunity to improve and can reduce the price variations, increase incomes for poor farmers, and promote rural development (Alemu and Adesina, 2015; Andri and Shiratake, 2005; Key and Runsten, 1999). It must be associated with an efficient program of technical assistance for quality improvements. Moreover, improvements in the judicial system (easier access and the lessening of bureaucracy) to enforce and make cheaper the enforcement of contracts may also help to solve the problem. 
Contracts depend on the level of coordination among the actors involved in the chain, but also from external factors, such as established institutes that guarantee their correct functioning.

\subsection{Communication and loyalty}

\section{- The barriers}

Disloyalty not only affects contract implementation, it also affects the producer-to-industry or member-tocooperative relations, where '.... any minor pressure under the producer, prompts a move to another company' (ID020). Nine interviewees mentioned that they are aware of this problem and would work to solve it because it increases logistic costs, the transparency, prevents supply and processing planning on industrial plants and quality standardisation, and affects the offer of technical assistance. Among the main causes of missing loyalty mentioned, we found that poor communication and information about benefits of loyalty from companies, cultural disloyal profile of the producer and the unfair competition in milk procurement, were all mentioned as factors.

\section{- The strategies}

Ten interviewees declared to have loyalty policies or incentives to retain producers. They work on strengthening loyalty with simple actions, which give some advantage and stability in production and transactions. The main action mentioned comprises of economic incentives, followed by actions involving the community and family, as well as offering support and technical assistance to producers. We found a very large scope of actions, varying from ' ...extra payments for the milk and encouraging farms to get the certificate [of brucellosis]' (ID019) to social actions like 'talks with experts about social aspects, drugs, violations ... and the offer of health insurance ... and funeral insurance' (ID013) for the families of producers, especially cooperative members. But apparently such actions do not have the desired effects on farmers' loyalty, since disloyalty persists and generates further problems.

Communication and loyalty also depends on the coordination mechanisms, but also on the culture and behavior of actors in the chain. They have an impact on other sources of competitiveness consequently.

\subsection{Processing capacities}

\section{- The barriers}

Processing companies also face high idle capacities' rates in their plants, which are also costly and generate inefficiencies. During the 1980s and 1990s, investment credits were given to cooperatives and other agricultural processing companies without technical and managerial support. So huge unplanned investments were made with these subsidized loans, with the building of large processing plants without any strategic plan for their supply or commercialising their production (Escher, 2011). Idle capacities affect processing plants that do not rely on sufficient milk suppliers because they cannot offer better prices to producers, cannot manage the seasonality, or simply because of an excess of infrastructure or poor management and planning. Seven persons interviewed noted this problem. 'Many industries are still working with idle capacity, which 'weighs' the production system' (ID026). They mention that 'this idle capacity is very costly' (ID014) generating losses and inefficiency. It is also linked to seasonality, disloyalty and control of supply, and poor management planning. 'In Santa Catarina the idle capacity was $40 \%$, which made it difficult to get financing from government credits' (ID017), for example. 


\section{- The strategies}

This problem may be addressed through the offer of technical assistance to control for low production effects of seasonality at farm level and establish contracts for supply control and loyalty. Furthermore, companies must establish strategic alliances or outsource the processing activities to other companies, which will allow the reduction of idleness and costs and even gains in economies of scale. Furthermore, it would also allow companies to differentiate the portfolio of products, allowing access to other markets and increase sales. Merge with other companies, reinvigorate and re-planning the processing plants according to specific market demands are also suitable to improve logistics and reduce idleness. Indeed the literature considers mergers and acquisitions, strategic alliances and outsourcing as important strategies to increase competitiveness.

According to our results seven companies are adopting strategic alliances or outsourcing. Managers, especially from cooperatives, are using this tool to seek to reduce their large idle capacities and increase the portfolio of products with low investments. We found cooperatives having'... many strategic alliances and also studying make new alliances to process products with other companies' (ID013). Outsourcing is also used in order to add value to the milk production or to participate in different channels of commercialisation, like, for example, the cooperative that '.. outsourced the powder milk production to participate in institutional programs from the government' (ID011). It is also very commonly found (seven companies) in transportation and logistics, which is a notable problem in the chain. Managers agree, '... it is much more organized now after outsourcing the logistics' (ID018), especially in controlling fraud in the chain. Outsourcing is a powerful strategic management tool as part of the global process to solve problems (Schneider, 2004). It could be used not only to mitigate the consequences of bad infrastructure in the chain, but also in any process in which the company is not able to perform with efficiency. It is useful to improve the costs structure, the global efficiency, reduce the idle capacities and most importantly, provide a rapid reaction capacity to market changes (Duque-Ceballos et al., 2014; Winkleman et al., 1993). Other advantages of externalising activities are the reduced investments in infrastructure, improved quality and efficiency and the fewer administrative and operational problems (Fill and Visser, 2000).

Interviewees also mentioned that '.. there is a tendency for merger between cooperatives to compete in scale' (ID008) against large private companies, but also to improve their costs structure and reduce idleness in processing plants through more efficient planning. Despite interviewees' awareness, we did not see much evidence for these mergers; thus they should occur faster and involve more cooperatives. Various successful examples of mergers and acquisitions all over the world reinforce this strategy, such as Fonterra, DFA, FrieslandCampina, Arla and others. For example, in USA the drivers of mergers and acquisitions were the structural changes in the food industry, the consolidation of the productive sector, the high price volatility of the 1990s and little consumption growth which, in turn, increased the intensity of competition and forced firms, mostly cooperatives, to gain in scale and improve their operational efficiency to successfully compete with private companies (Chaddad, 2007). Similar events have been observed in Brazil in the last years. Nevertheless, the proportion of organisations adopting such strategies in GFM is still quite low, because of disorganisation in the sector or internal conflicts.

Processing capacities are mostly affecting the production economies of size and scope. Coordination, differentiation and management capacities may also influence the processing organisation and idleness' levels in a company.

\subsection{Investments}

\section{- The barriers}

In terms of investments, five interviewees, representing large cooperatives and private companies, argued that there is low level of investment in the sector, especially in marketing and RTDI. They say that in general, managers still consider marketing an expense rather than an investment, arguing that 'there is a very poor 
culture of investment in RTDI and marketing' (ID023) as consequence of non-professionalisation of the chain. Only six participants mentioned marketing as an important investment. Among cooperatives, only a few are '... investing in marketing and branding' (ID008). They focus more to 'invest in social programs, community programs, and quality..., to maintain the producer [loyalty] and avoid losses to privates [companies]' (ID015). Furthermore, specific internal conflicts inside cooperatives interfere when investment decisions have to be taken '...for financial reasons and weak professionalism of directors' (ID011). In this regard directors and managers are aware that '.. the cost for the company to do the marketing directly with the consumer is very expensive; but the return pays off.' (ID026).

Seven participants affirm that they invest in RTDI to improve competitiveness, however 'there is still a huge gap to improve and create more products, companies should also diversify the presentation of the products, the types and sizes of packages' (ID004). In terms of differentiation only two interviewees confirm that their companies have implemented product differentiation as a strategy; and four believe that companies have difficulties in differentiating products, but should do it to increase their profits, especially the 'micro and small companies should differentiate products in order to have gains in the niche markets' (ID007).

\section{- The strategies}

It is possible, however, to find a few positive examples. Some companies 'release new products every year. Have a department of innovation and RTDI for innovation' (ID012) or even run '[on the cooperative] an experimental center (RTDI) to develop technologies of pasture-based milk production. Also some have an experimental dairy farm' (ID008) or '[on the cooperative] a team working on products development and quality' (ID014). RTDI are fundamental to developing products, processes, and technology in order to be more competitive. Moreover, the enrichment of the technological patrimony contributes towards the capacity for constant market adaptation and competition changes. In terms of the governmental investment programs, the state of 'Santa Catarina has invested a lot in technology and genetics. It is also the only state free of foot-and-mouth disease without vaccination' (ID023). The capital for investment comes mainly from governmental development banks, or in some cases, the capital is a mixture of both credits and own capital.

Investments are mostly affected by the capacity and intention of managers (inputs), but also by different external factors such as governmental policies and macroeconomic variables influencing the availability of credits for a specific sector. The level of investments may be determinant for other sources of competitiveness, for instance technology, other inputs, production economies and the differentiation of products through innovation, quality and advertising for example.

Cooperative business organisations play a significant role in GFM (Beber et al., 2018). This kind of horizontal arrangement can improve the competitiveness and the livelihood of farmers in through mechanisms guaranteeing better market access and power, enhancing productivity, technology access, among others (de Brito et al., 2015). However cooperatives face additional higher restrictions and challenges in GFM regarding investments in RTDI. There are common problems implicit in traditional cooperatives ${ }^{\prime}$ organisational characteristics affecting investments decisions and increasing competitiveness constraints. These problems are related to the vaguely defined property rights in these cooperatives, which result in the so-called 'freerider', 'investment horizon', 'portfolio', 'influence costs' and 'control' problems (see Cook (1995) for a description of each problem).

Cook and Iliopoulos (1998), and Iliopoulos and Cook (2013) propose a set of actions and measures to overcome the aforementioned property right problems in cooperatives. They involve a relaxation in the organisational characteristics of 'traditional cooperatives' with the definition of individual delivery rights (defined volumes) and mechanisms to allow the transferability, liquidity and appreciation of membership rights. Among these actions are: the creation of incentives for risk capital investment with a base capital

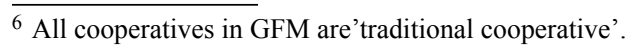


plan for investments with up-front equity, closed membership and singleness of purpose to control quality and quantity of supply, constant communication and a contractual agreement with members to create a sense of belonging and commitment, among others. The latter has also been referred to as supplier relationship management (Gyau et al., 2011). The implementation of such measures in GFM could help cooperatives to avoid several problems and increase their competitiveness. To achieve this, the government must update the outdated and inflexible Brazilian cooperatives law (Law No 5.764, 16/12/1971).

\subsection{Transport costs}

\section{- The barriers}

The region also faces problems with high costs related to the transport of milk from the farms to the plants. The main reasons are the poor infrastructure related to '...the bad situation of the roads' (ID002) in addition to the large distances to collect low volumes from small producers, which 'make higher the cost of milk procurement' (ID003). For example, in the SW-PR the average of distance to collect the milk is around 149 $\mathrm{km}$ (two-ways) for the large companies, with the extreme of $617 \mathrm{~km}$ in one of the cases, and the volumes to collect are on average 55 liter/day/producer (IPARDES, 2010). This situation raises the costs of collection, especially for the cooperatives having a social role in rural areas. Moreover, during the rainy season, access becomes even more difficult and expensive. The consequence is that 'volumes are taken into account to exclude some farms because of logistics ... the transport costs are too expensive' (ID019). The problems not only lie in collecting the milk, but also to transporting inputs to the farm as well as provide technical assistance to remote farmers.

\section{- The strategies}

Ten interviewees, including institutions, cooperatives and private companies, conclude that this problem could be improved by developing the supply chain. 'Increasing volumes per farm, and maintaining good routes to access the farms can solve those problems' (ID010). This issue involves the provision and maintenance of the public works service by the local/state governments, in which the producer has low or no direct control. A reliable and stable provision of electricity on the farms is also a fundamental infrastructural ambition since dairy farms have to keep the milk cooled for at least two days before collection (Escher, 2011).

Several studies show the importance of maintaining good infrastructure on costs, prices, market and information access, rural development and livelihood enhancement (Mu and van de Walle, 2007; Ndiaye et al., 2015; World Bank, 1994). In GFM companies are dealing with such barrier in different ways. First through technical assistance in order to raise farmers' total production. Collecting more milk from each farm reduces time of collection optimising the milk collected per day, per truck and per driver. To facilitate the collection, companies also installed cooling stations in centralized areas where the milk is brought by farmers or small trucks belonging to the company. From there, larger trucks take the milk to processing plants. Second, outsourcing the milk collection is also a strategy been used in GFM. Companies want to avoid the complexity that milk collection involves and focus on their core competencies, letting the transport to companies specialized on that. Transport requires an important mobilisation of people for the logistics, driving, buying and repairing trucks, inspection controls in the trucks, among others. Processing companies also use lobbying with the local authorities for the improvement of road infrastructures.

Volumes of milk (inputs) affect the transport costs, but also the situation of the roads and accesses to farms that depend on governmental interventions (external factors). Coordination mechanisms might also alleviate or increase the transport costs. 


\subsection{Entry of large companies}

GFM is a very dynamic and fast growing region in dairy production. Large companies have been installing plants in the region ${ }^{7}$ and competing for the procurement of milk, provoking controversy among interviewees. Some believe that these companies will develop the dairy sector by stimulating the improvement in techniques to achieve greater competitiveness. Others think that these companies harm the smallest ones, and bring negative consequences establishing a monopsonistic position in the milk procurement of some areas with an anticompetitive effect.

\section{- The barriers}

There are those, especially some institutes that '... see future conflicts in the chain because companies are expanding and arriving in the production zone to procure the milk, but there is not enough milk for everybody' (ID002). 'Large companies are creating more refrigeration stations to collect milk in remote areas and they are competing against the small [companies] in the procurement of milk' (ID003). 'It will be hard for cooperatives to compete. Companies will compete in the milk procurement and [...] will probably 'steal' producers from others' (ID001).

Some large companies have a high level of professionalisation on their teams, with a good education and training level for employees and skilled managers; a scenario which is widely different from the smaller ones, especially singular cooperatives that ' .... are managed by producers in most cases. And they don't have many managerial skills...' (ID018). In this regard an important aspect recognized by the interviewees that must be prioritized is the social role of cooperatives who are perceived to be '...different from other private firms because [we] work in the development of the region with actions to improve the farmers' wellbeing, socially and economically' (ID008). Small cooperatives 'are closer to the producer and have an important social service in the communities ... they have a function of income distribution in rural areas' (ID003); '...investing in social programs, technical assistance, culture, community programs, quality, pasture' (ID015) to '...maintain the young in the farms and also a program for the women' (ID013). Excluding such organisations may generate a social problem in some rural areas. For instance, it is difficult to exclude inefficient producers, and at the same time consider that the situation of the members depends on the economic success of the cooperative; and they compete against for-profits corporations that have a clear market orientation (Carvalho, 2008).

\section{- Another view of the 'problem'}

On the other hand there are those who affirm that 'the entry and expansion of large companies increases the competitiveness of the sector' (ID003) and it 'brings improvements in the competitiveness, boosting production and innovation' (ID012) so that the sector is '....becoming competitive, professional instead of familiar and that raises the prices [for producers]' (ID009).

Actually the dairy chain has experienced significant concentration at all levels in most OECD (Organisation for Economic Co-operation and Development) countries (OECD, 2000). In the Southern region of Brazil, from the 469 processing companies existing in 2012, only $383(-18 \%)$ still remained in 2017, while the volumes collected are stable at around 8.6 billion liters per year. Efficiency gains and countervailing market power arguments have been offered as explanations for increases in concentration at various stages of the dairy supply chain.

Furthermore, as profit margins decline, increasing concentration is inevitable, in order to spread fixed costs and remain competitive (Sutton, 2003). Porter (1990) considers that rivalry generates pressure on competitors and stimulates sustainable and continuous growth to maintain competitive advantages. The process of concentration

\footnotetext{
${ }^{7}$ Nestlé installed two plants in 2008 and 2010. Lactalis arrived in 2014 and is already the largest group in GFM. Other large companies include Tirol, Italac, Piracanjuba, etc. The largest cooperatives are CCGL installed in 2008 and Aurora, which started processing milk only in 2004.
} 
and internationalisation is inevitable in the modernisation of a supply chain, but these processes should happen in a fair way, especially to the small producers who are the most affected. In this regard the mergers and acquisitions of small companies (cooperatives) would be an important strategy to realize gains in scale and bargaining power. The professionalisation of the management of such companies is also fundamental, though. Otherwise the consequences of monopolies would be lower returns to farmers, increased risk in farming activities and the cut-off of more farmers and small companies, especially cooperatives.

External factors such as governmental incentives may be one of the reasons why companies move to a region, but also because of the macroeconomic stability in the country. Supply competition, logistics and coordination mechanisms are also generally involved in such decisions.

\subsection{Frauds}

\section{- The barriers}

Several interviewees complained about frauds in the chain, identifying two common types of fraud. The first type of fraud was 'the huge problems with payment defaults... This discouraged production because everybody is afraid' (ID019). At least four interviewees said they had been victims of this type of cheat. 'Frauds and payment defaults are factors that break producers' (ID015). The second type of fraud is adulteration of the milk; when the sector faces low prices, low production and payments per volume, farmers and transporters, but also people responsible for cooling stations, add water and other substances to the milk in order to increase the volume for delivery. Since 2013, the MAPA has developed tests and penalties to combat these fraudulent actions. Through the 'Operação Leite Compensado' they discovered adulterations in the milk and some representatives of cooperatives and private companies who were aware of the fraud. Thus, the image of the whole chain and the products of the companies involved was tarnished.

\section{- The strategies}

Companies defend themselves against the second type of fraud by constantly taking samples of the milk, doing '... frequent and rigorous tests of the milk, ...' (ID010) and punishing the persons responsible when fraud is detected. This type of scam had directly or indirectly affected ten interviewees.

Fraud in dairy chain occurs often, especially in countries where regulations and inspections are deficient. Our study shows that frauds in GFM are mainly a result of altering volumes. The impacts of adulterating milk go further than just fooling buyers though: they imply serious consequences to consumers' health, since in general non-potable water, detergents, urea, hydrogen peroxide, caustic soda, and other toxics are added. Handford et al., (2016) present a broad review of the literature on milk fraud in developing countries outlining the impact on nutrition, food safety and consumer confidence. They illustrated that milk is adulterated in high percentages, reaching more than $70 \%$ in some cases, with the aim to obtain financial gains. They also mention that these practices represent a common problem in developing countries where there are unregulated practices, inefficient inspection systems and low food safety standards. Scott and Costello (1985) mentioned the existence of these frauds to increase volumes by adding water, emphasized in the informal distribution channels in Latin American countries. In Brazil, Souza et al. (2011) conducted an analysis for adulterants in 100 samples of UHT milk and found nonconformities of up to $55 \%$ of them. This discourages potential national and international consumers, and downgrades the image of the product and the chain. In order to guarantee that such problems would not be repeated, the government and sector authorities should review the actions conducted by other countries - like in some European countries and the USA where this problem is much more thoroughly controlled. The actions of these countries are focused on organising an efficient inspection system, with updated detection methods and the conduction of regular audits on suppliers, as well as training of the personnel involved in the operations and a good education for farmers to avoid malpractice (Handford et al., 2016). The government must act severely regarding the enforcement of measures to prevent fraud. 
External factors influenced by governmental regulations and its capacity of enforcement are behind such frauds. Cultural behavior and coordination mechanisms may also influence the existence of frauds.

Figure 4 illustrates the primary findings. The barriers and strategies identified can directly or indirectly affect on one or more sources of competitiveness of the Harrison and Kennedy (1997) framework.

\section{Conclusions and policy implications}

This research shows that the dairy sector in GFM region is still far from being competitive at the international level, since the productive chain still has several factors to improve. Therefore, this scenario urges urgent measures to promote and guide the necessary structural changes, increase competitiveness and contributing to future growth on firms that seek and compete for positioning in the market. Such changes involve not only technological improvements in machinery, equipment, and materials, but also processes and methods of organisation and coordination (Dries et al., 2009); all with the common objective of increasing efficiency in production and contributing to a an environment conductive for innovation.

'Productivity' is one of the fundamental pillars to increase competitiveness through the adoption of technology, an adequate scale of production, and increases in efficiency. To raise the productivity level of the dairy sector of Southern Brazil, it is necessary to improve the level of professionalism in the whole chain. This includes professionalisation at production level with farmers more attentive to the farms' productive, environmental and economic performances, but also at the processing level with more skilled workers and managers to achieve higher quality, innovation and technological levels and further market access, both national and international. Moreover, 'product quality' is a key factor in developing the chain. It requires better managerial practices and the implementation of higher quality standards that allow the development of high quality products with the potential to access international markets. In developing and transition economies, efficiency tends to spread in a top-down flow. Thus, it is necessary to improve the provision of training and technical assistance to farmers in order to spread the new technologies and techniques already available. Since companies are mainly responsible for such technical assistance, more professional and competitive companies are able to spread them more efficiently to their farmers. Therefore, management professionalisation at processing level is one of the first steps to improve the competitiveness of the whole supply chain.

In the management of agri-food enterprises there still often exists a culture of low innovation and resistance to changes, especially in concerning entrepreneurship. To overcome this, the strategy and vision of the corporation must be clear, planned and well defined, with a professional and specialised profile understanding the market dynamics; making correct decisions, in correct moments, with the correct resources, boosting the evolution of the corporation to compete.

In Brazil, the problems could be much more alleviated if the government improved the infrastructure, the judicial security, the inspection and control system and promoted the diffusion of technologies already available for the dairy production and management. The government must also anticipate, encourage and/or pressure the companies and farmers to raise their aspirations and their competitive performance by creating an environment that facilitates the development of competitive advantages. But, at the same time, the government has to improve institutional procurements, microfinance, rural extension, education, professionalisation and entrepreneurship at the rural level, so that small producers are not excluded but have awareness of how to progress and adapt to the competitive market.

This research has limitations. First, it is limited by the scope of the interviewees. Future research should include the farmers' point of view into the analysis of competitiveness of the general sector. That would make it possible to see the context from another angle, which sometimes could be contrasted to those of other stakeholders in the chain. Small processing companies should also be included. Second, this research is limited by the case study area, where only the Southern Brazil is represented. However, there are similarities 
with other dairy production zones, especially in neighboring states and countries, which could be also analyzed in future studies.

\section{Funding}

This work was supported by the Coordenação de Aperfeiçoamento de Pessoal de Nível Superior (CAPES).

\section{References}

Albu, M. and A. Griffith. 2006. Mapping the market: participatory market-chain development in practice. Small Enterprise Development 17 (2): 12-22. https://doi.org/10.3362/0957-1329.2006.016

Alemu, A.E. and J. Adesina. 2015. Effects of co-operatives and contracts on rural income and production in the dairy supply chains: evidence from Northern Ethiopia. African Journal of Agricultural and Resource Economics Volume 10 (4): 312-327.

Andri, K.B. and Y. Shiratake. 2005. Empirical study of contract farming system conducted by dairy cooperatives in east Java, Indonesia. Available at: http://dairyasia.org/file/Information/Dairy\%20farms\%20East\%20 Java\%20(Study).pdf.

Anschau, C.T. 2011. Redes Cooperativas da Bovinocultura de Leite e o Desenvolvimento do Oeste Catarinense. Available at: https://www.unochapeco.edu.br/static/data/portal/downloads/926.pdf.

Austin, J.E. 1981. Agroindustrial project analysis, EDI series in economic development. Johns Hopkins University Press, Baltimore, MD, USA.

Batalha, M.O. and H.M. Souza Filho. 2009. Analisando a Competitividade de Cadeias Agroindustriais: uma proposição metodológica. Agronegócio No MERCOSUL Uma Agenda Para O Desenvolv. São Paulo Atlas 1-22.

Beber, C.L., L. Theuvsen and V. Otter. 2018. Organizational structures and the evolution of dairy cooperatives in Southern Brazil: a life cycle analysis. Journal of Co-Operative Organization and Management 6 (2): 64-77. https://doi.org/10.1016/j.jcom.2018.06.003

Benson, T., 2014. Building good management practices in Ethiopian agricultural cooperatives through regular financial audits. Journal of Co-Operative Organization and Management 2 (2): 72-82. https://doi. org/10.1016/j.jcom.2014.10.001

Brunetti, A., G.B. Kisunko, B. Aymo Weder and B. Weder. 1999. Institutional obstacles to doing business: region-by-region results from a worldwide survey of the private sector. The World Bank. Available at: https://doi.org/10.1596/1813-9450-1759.

Carraresi, L. and A. Banterle. 2015. Agri-food Competitive performance in EU countries: a fifteen-year retrospective. International Food and Agribusiness Management Review 18 (2): 37-62.

Carvalho, M.P. de, P. do C. Martins, J.T.C. Wright and R.G. Spers. 2007. Cenários para o leite no Brasil em 2020. Embrapa Gado de Leite, Juiz de Fora. Available at: https://tinyurl.com/y5hlts3z.

Carvalho, V.R.F. 2008. Tese - reestruturação do sistema lácteo mundial: uma análise da inserção Brasileira. Universidade Estadual de Campinas - Instituto de Economia. Available at: http://repositorio.unicamp. br/bitstream/REPOSIP/285788/1/Carvalho_VeraReginaFerreira_D.pdf.

Chaddad, F.R. 2007. Cooperativas no agronegócio do leite: mudanças organizacionais e estratégicas em resposta à globalização. Organizações Rurais \& Agroindustriais 9 (1): 69-78. http://200.131.250.22/ revistadae/index.php/ora/article/viewArticle/149.

Chaddad, F.R. and M.S. Jank. 2006. The evolution of agricultural policies and agribusiness development in Brazil. Choices 21 (2): 85-90.

Cook, M.L. 1995. The future of U.S. agricultural cooperatives: a neo-institutional approach. American Journal of Agricultural Economics 77 (5): 1153-59. https://doi.org/10.2307/1243338

Cook, M.L. and M.E. Bredahl. 1991. Agribusiness competitiveness in the 1990s: discussion. American Journal of Agricultural Economics 73 (5): 1472. https://doi.org/10.2307/1242404

Cook, M.L. and Iliopoulos, C., 1998. Solutions to property rights constraints in producer-owned and controlled organizations: prerequisite for agri-chain leadership? In: Proceedings of the Third International Conference on Chain Management in Agri Business and Food Industry, Ede, 28-29 May 1998, p. 541. 
De Brito, M.M., F.I. Bánkuti, S.M.S. Bánkuti, G.T. dos Santos, J.C. Damasceno and E.M. Massuda. 2015. Horizontal arrangements and competitiveness of small-scale dairy farmers in Paraná, Brazil. International Food and Agribusiness Management Review 18 (4): 155-72.

Dries, L., E. Germenji, N. Noev and J.F.M. Swinnen. 2009. Farmers, vertical coordination, and the restructuring of dairy supply chains in central and eastern Europe. World Development 37 (11): 1742-58. https:// doi.org/10.1016/j.worlddev.2008.08.029

Duque-Ceballos, J.L., C.H. González-Campo and M. García-Solarte. 2014. Outsourcing y Business process outsourcing desde la teoría económica de la agencia. Entramado 10 (1): 12-29.

Escher, F. 2011. Os Assaltos do Moinho Satânico nos Campos e os Contramovimentos da agricultura familiar (master in rural development). Universidade Federal do Rio Grande do Sul, Porto Alegre, RS.

FAO, OECD, 2015. OECD-FAO Agricultural Outlook 2015. OECD-FAO Agricultural Outlook. OECD Publishing. Available at: http://dx.doi.org/10.1787/agr_outlook-2015-en.

FAOSTAT, 2019. Food and Agriculture Organization of the United Nations. FAOSTAT Statistics Database. Available at: http://www.fao.org/faostat/en/\#home.

Farina, E.M.M.Q. 2003. The Latin American perspective on the impacts of the global food economy: the case of Brazil. Presented at the Conference on Changing Dimensions of the Food Economy: Exploring the Policy Issues, 6-7 February 2003, The Hague, Netherlands. Available at: http://www.fundacaofia. com.br/PENSA/anexos/biblioteca/133200715223_.pdf.

Ferrari, D.L., M.A. Mello, V.M. Testa and M.L. Silvestro. 2005. Agricultores familiares, exclusão e desafios para inserção econômica na produção de leite em Santa Catarina. Informações Econômicas São Paulo 35: 22-36.

Feurer, R. and K. Chaharbaghi. 1994. Defining competitiveness: a holistic approach. Management Decision 32 (2): 49-58. https://doi.org/10.1108/00251749410054819

Fill, C. and E. Visser. 2000. The outsourcing dilemma: a composite approach to the make or buy decision. Comprehensive Reviews in Food Science and Food Safety 15 (1): 130-42. https://doi.org/10.1108/ EUM0000000005315

Gyau, A., A. Spiller and C. Wocken. 2011. Price or relational behaviours? Supplier relationship management in the German dairy industry. British Food Journal 113 (7): 838-52. 838-852. https://doi. org/10.1108/00070701111148388

Handford, C.E., K. Campbell and C.T. Elliott. 2016. Impacts of milk fraud on food safety and nutrition with special emphasis on developing countries: health impacts of milk fraud. Comprehensive Reviews in Food Science and Food Safety 15 (1): 130-42. https://doi.org/10.1111/1541-4337.12181

Harrison, W.R. and P.L. Kennedy. 1997. A Neoclassical Economic and Strategic Management Approach to Evaluating Global Agribusiness Competitiveness. Competitiveness Review 7 (1): 14-25. https://doi. org/10.1108/eb046342

Helfand, S., A.R.B Moreira and E.W. Bresnyan Jr. 2015. Agricultural productivity and family farms in Brazil: creating opportunities and closing gaps. World Bank, Washington, DC, USA.

Hudson, M.A. 1990. Toward a framework for examining agribusiness competitiveness. Agribusiness 6 (3): 181-189.

IBGE, 2006. Censo Agropecuário 2006. Available at: https://tinyurl.com/y5elhqqc.

IBGE. 2014. Instituto Brasileiro de Geografia e Estatística. http://www.ibge.gov.br/home/.

IBGE, 2017. IBGE :Instituto Brasileiro de Geografia e Estatística [WWW Document]. URL http://www. ibge.gov.br/home/ (accessed 10.26.15).

Iliopoulos, C. and M.L. Cook. 2013. Property rights constraints in producer-owned firms: solutions as prerequisites for successful collective entrepreneurship. Selected Paper prepared for presentation at the International Conferences on Economics and Management of Networks -EMNet, 21-23 November 21-23, 2013, Agadir, Morocco.

IPARDES, 2010. Caracterização da Indústria de Processamento e Transformação do Leite no Paraná. Available at: http://www.ipardes.gov.br/pdf/caracterizacao_industria_leite.pdf.

Jank, M.S., E. Farina and V.B. Galan. 1999. O agribusiness do leite no Brasil. Milkbizz/PENSA, Sao Paulo, Brazil. 
Jank, M.S. and V.B. Galan. 1998. Competitividade do sistema agroindustrial do leite. IPEA/PENSA/USP, Sao Paulo, Brazil.

Kennedy, P.L., R.W. Harrison and M.A. Piedra. 1998. Analyzing agribusiness competitiveness: the case of the United States sugar industry. The International Food and Agribusiness Management Review 1 (2): 245-57.

Kennedy, P.L., W. Harrison, N.G. Kalaitzandonakes, C.P.H and R.P. Rindfuss. 1997. Perspectives on evaluating competitiveness in agribusiness industries. Agribusiness 13 (4): 385-392.

Key, N. and D. Runsten. 1999. Contract farming, smallholders, and rural development in Latin America: the organization of agroprocessing firms and the scale of outgrower production. World Development 27 (2): 381-401.

Khidirov, D. 2017. Disclosable Version of the ISR - Horticulture Development Project - P133703 - Sequence No : 07. Available at: https://tinyurl.com/yxsrjqky.

Lacki, P. 1998. La formación de profesionales para profesionalizar a los agricultores. REVISTA CEIBA 39 (1): 25-37.

Lopes, M.R., G. da S. Souza, I.G.V. Lopes and G. Honczar. 2002. Gestão estratégica e reformas nas cooperativas agropecuárias Brasileiras. Agronegócio Cooperativo: Reestruturação e Estratégias. Viçosa: Suprema 1-54.

Madalena, F.E., L.L. de Matos and E.V. Holanda Júnior. 2001. Produção de leite e sociedade: uma análise crítica da cadeia do leite no Brasil. Available at: http://www.fernandomadalena.com/site_arquivos/900.pdf.

Martin, L., R. Westgren and E. van Duren. 1991. Agribusiness competitiveness across national boundaries. American Journal of Agricultural Economics 73 (5): 1456-64. https://doi.org/10.2307/1242402

MDIC. 2016. Ministry of Development, Industry and Foreign Trade. Available at: http://www.mdic.gov.br/.

MDIC, 2019. Comex vis: visualizações de comércio exterior. Available at: http://www.mdic.gov.br/comercioexterior/estatisticas-de-comercio-exterior/comex-vis.

Milk Brazil. 2017. $21^{\circ}$ Ranking maiores empresas de laticínios do Brasil - 2017. Available at: http:/www. leitebrasil.org.br/download/maiores\%20laticinios\%202017.pdf.

$\mathrm{Mu}, \mathrm{R}$. and D. P. van de Walle. 2007. Rural roads and poor area development in Vietnam. World Bank Policy Research Paper 4340. Available at: https://papers.ssrn.com/sol3/papers.cfm?abstract_id=1012218.

Mueller, B. and C. Mueller. 2014. The economics of the Brazilian model of agricultural development. International Research Initiative on Brazil and Africa 62:12-20.

Ndiaye, M., E.M. d'Hôtel and T. Le Cotty. 2015. Maize price volatility: does market remoteness matter? World Bank Policy Research Paper 7202. Available at: https://tinyurl.com/y3yf7toa.

Neves, M.F., G. Trombin and R.B. Kalaki. 2013. Competitiveness of the orange juice chain in Brazil. International Food and Agribusiness Management Review 16 (4): 141-158.

Nivievskyi, O. 2012. Increasing the Competitiveness of the dairy supply chain in Ukraine: role of the government. Policy paper. Available at: https://tinyurl.com/yxza3arl.

Porter, M.E. 1990. The competitive advantage of nations. Harvard Business Review 68 (2): 73-93.

Porter, M.E. 1985. Competitive advantage: creating and sustaining superior performance. Free Press, New York, NY, USA.

Porter, M.E. 1980. Competitive strategy: techniques for analyzing industries and competitors: with a new introduction. Free Press, New York, NY, USA.

Schneider, B. 2004. Outsourcing: la herramienta de gestión que revoluciona el mundo de los negocios. Grupo Editorial Norma, Colombia.

Schwab, K., X. Sala-i-Martin and B. Brende. 2015. The Global competitiveness report 2015-2016 (Vol. 5). Available at: http://www3.weforum.org/docs/gcr/2015-2016/Global_Competitiveness_ Report_2015-2016.pdf.

Scott, G.J., Costello, M.G. (Eds.), 1985. Comercialización interna de los alimentos en América Latina: problemas, productos y políticas. Available at: https://tinyurl.com/y6dfbb2v.

Sharples, J. amd N. Milham. 1990. Longrun competitiveness of Australian agriculture (No. 243). United States Department of Agriculture. Available at: https://tinyurl.com/y4bd266f.

Solow, R.M. 2001. Applying growth theory across countries. The World Bank Economic Review 15 (2): 283-288. 
Souza, S.S., A.G. Cruz, E.H.M. Walter, J.A.F. Faria, R.M.S. Celeghini, M.M.C. Ferreira, D.G. and A. de S. Sant'Ana. 2011. Monitoring the authenticity of Brazilian UHT milk: a chemometric approach. Food Chemistry 124 (2): 692-95. https://doi.org/10.1016/j.foodchem.2010.06.074

Sutton, J. 2003. Understanding the rise in global concentration in the agri-food sector: a background paper. Presented on OECD Conference on Changing Dimensions of the Food Economy, 6-7 February 2003, The Hague, the Netherlands.

Theuvsen, L. and O. Ebneth. 2005. Internationalization of cooperatives in the agribusiness - concepts of measurement and their application. In: Strategies for Cooperation, edited by T. Theurl and E. Christian Meyer. shaker Verlag GmbH, Aachen, Germany, pp. 395-419.

Tybout, J.R. 2000. Manufacturing firms in developing countries: how well do they do, and why? Journal of Economic Literature 38 (1): 11-44.

Winkleman, M., P. Dick and M. Lee. 1993. The outsourcing source book. The Journal of Business Strategy 14 (3): 52.

World Bank. 1994. World development report 1994: infrastructure for development. Available at: https:// openknowledge.worldbank.org/handle/10986/5977.

Young, G.J., M.P. Charns and S.M. Shortell. 2001. Top manager and network effects on the adoption of innovative management practices: a study of TQM in a public hospital system. Strategic Management Journal 22 (10): 935-51. https://doi.org/10.1002/smj.194 
